\title{
IMPACT AND BALLISTIC RESISTANCE OF A NEW ALUMINIUM ALLOY FOR SHIP CONSTRUCTION ELEMENTS
}

\author{
Wojciech Jurczak, Ph. D. \\ Polish Naval Academy, Poland
}

\begin{abstract}
The article presents results of examination of the new alloy $7020 \mathrm{M}$ intended to be used in shipbuilding. The examination concerned impact properties, verified on a numerical model, and the resistance to perforation (ballistic resistance). Impact and ballistic resistance tests aimed at increasing the operational safety of marine construc-tions to be made of this alloy under the threat of gunfire or explosion.

Dynamic loading of the alloy $7020 \mathrm{M}$ leads to the increase of its strength, as compared to the static load, with the range of this increase depending on the strain rate. Splitting of the structure made of the alloy $7020 \mathrm{M}$ increases its impact resistance by three times when preserving the same thickness $(g=12 \mathrm{~mm} \Leftrightarrow \Rightarrow g=2 \times 6 \mathrm{~mm})$. The alloy examined in the structurally homogenous form revealed low resistance to perforation, while the use of $6 \mathrm{~mm}$ thick ballistic ceramic $\left(\mathrm{Al}_{2} \mathrm{O}_{3}\right)$ fully protected this material against damage done by $€ P S$ 7,62 $\mathrm{mm}$ shells having the energy of $3 \mathrm{~kJ}$. The split structure of the alloy ensured better protection against explosive pieces formed during 1,4 $\mathrm{kg}$ TNT explosion than the homogeneous structure having the same thickness.
\end{abstract}

Keywords: ship aluminium alloy, impact and ballistic resistance, light ship construction, operational safety

\section{INTRODUCTION}

Due to their properties, aluminium alloys are widely used not only in shipbuilding, but al-so in constructions of many land transportation means. The economy of contemporary sea transport requires large speeds of both passenger navigation and cargo transportation. Agree-ments which define deadlines for deliveries by sea do not take into account weather conditions, therefore watercraft units are frequently exposed to impact loads during severe weather condi-tions. Such loads of ship structures can be observed during high-speed navigation on heavy sea. For safety reasons, the state of sea equal to $3^{\circ} \mathrm{B}$ makes navigation impossible for such watercraft units as hydrofoil ships, catamarans, etc., but in emergency situations, resulting for instance from rapid weather changes, these units should also reveal sufficient impact resistance. The above type of impact actions and their possible consequences are, and should be, taken into account when designing a ship construction, in particular that of a warship. As a special type of watercraft exe-cuting specific tasks, the warship is exposed to impact (dynamic) action having high energy den-sity, for instance the impact of a shell moving with high velocity (above $500 \mathrm{~m} / \mathrm{s}$ ), or the shock wave pressure pulse generated by indirect underwater or direct surface explosion. The resistance of the material used for building the ship construction to the action of the abovementioned munitions bears the name of the resistance to perforation, or more commonly: the ballistic resistance.
Maritime piracy, widespread nowadays, forces the use of constructions revealing in-creased impact resistance also for merchant ships to protect the crew and equipment against gun-fire [6].

The new alloy $7020 \mathrm{M}$ is intended to be used for ship construction plating. It is one of the best aluminium alloys among those presently used in shipbuilding [7]. Positive results of laborato-ry impact tests of series 7000 alloys [8] have made the basis for field tests of the new alloy $7020 \mathrm{M}$ as well as the alloy 7020 (PA47tb), intended to be used for combat ship constructions.

\section{SIMPLIFIED MATHEMATICAL MODEL}

Sheet splitting which preserves the same thickness, or replacing a construction element by at least two thinner elements, not necessarily made of the same material but having the total thickness not exceeding that of the initial element and not surface-connected with each other, leads to the increase of the impact and ballistic resistance. Such elements absorb much more en-ergy during deformation without loss of structural integrity (cracks), and consequently reveal several times higher impact resistance [9]. This conclusion was formulated after comparing dia-grams of stretching of synthetic fibres in fabrics used for bulletproof vests. It was stated that the kevlar fibre, the best of those being the objects of comparison, reveals the 
highest tear resistance and the best stretching ability. That means that it can accumulate most energy during defor-mation before it is torn apart.

The elastic deformation energy of a homogeneous two-support test sample loaded with static transverse force can be calculated using the formulas 1-3:

$$
\begin{gathered}
f=\frac{F}{k}=\frac{F l^{3}}{4 E 8 J}=\frac{F l^{3}}{4 E b^{3} h} \\
\sigma=\frac{R_{A} \cdot \frac{1}{2} l}{W}=\frac{\frac{1}{2} F \cdot \frac{1}{2} l}{\frac{b h^{2}}{6}}=\frac{3 F l}{2 b h^{2}} \\
\Phi=\frac{1}{2} F f=\frac{1}{2} k f^{2}=\frac{F^{2} l^{3}}{96 E J}=\frac{F^{2} l^{3}}{8 E b h^{3}}
\end{gathered}
$$

where:

f-maximal deflection, $\Phi$-potential energy, $\sigma$-maximal stress, G-shear modulus, F-static force, h-thickness of the homogeneous test sample, $b$-width of the homogeneous test sample

The same calculation algorithm was applied for the split sample of the same thickness, assuming that $\mathrm{h} 1=\mathrm{h} 2=0,5 \mathrm{~h}$. The scale of the obtained elastic deformation and the remaining parameters for the split sample are defined by formulas 4-6.

$$
\begin{gathered}
f_{d}=f_{0.5}=\frac{\frac{1}{2} F}{k_{0.5}}=\frac{F l^{3}}{E b h^{3}}=4 f \\
\sigma_{d}=\sigma_{0.5}=\frac{\frac{1}{2} R_{A} \cdot \frac{1}{2} l}{\frac{b h^{2}}{6 \cdot 4}}=\frac{3 F l}{b h^{2}}=2 \sigma \\
\Phi_{d}=2 \Phi_{0.5}=2 \cdot \frac{1}{2} \cdot \frac{1}{2} F f_{0.5}=\frac{F^{2} l^{3}}{2 E b h^{3}}=4 \Phi
\end{gathered}
$$

where:

d-index concerning the split sample

The above simplified mathematical model does not take into account deformation generated by shear forces. Nevertheless, it has been positively verified in impact experiments and numerical simulations.

\section{IN-HOUSE TESTS}

The methodology of the tests, as well as the shapes and dimensions of the samples used in the tests, meet the requirements of: Polish Standards, Polish Register of Shipping, and Regula-tions on Shipbuilding and Defence Standards. The impact and ballistic resistance was determined in accordance with STANAG-u 4569.

The tools used in the laboratory tests included a conventional Charpy hammer and a spe-cially instrumented rotating hammer [3] which reveals the ability to tear with the impact speed of up to $50 \mathrm{~m} / \mathrm{s}$. The research rig for perforation (ballistic) resistance tests is described in [5] and is the essence of the PNA patent under further modification, authors: Fila, Zatorski. The field tests oriented on determining the behaviour of homogeneous and split structures of the alloy $7020 \mathrm{M}$ exposed to perforation with explosive pieces after 1,4 $\mathrm{kg}$ TNT detonation were performed on the training ground in accordance with STANAG-u 4569.

\section{CHEMICAL COMPOSITION AND MECHANICAL PROPERTIES OF 7020M ALLOY}

The test samples were made form sheets of 7020M alloy obtained from two melts differ-ing by chemical composition. The chemical compositions of the alloy 7020M T651 melts are given in Table 1. Standardised samples of the alloy were exposed to the static tensile test, the results of which, determined as the average values for three samples, are shown in Fig.1. The test samples had either homogeneous or spilt structure of the same thickness. The impact resistance was de-termined for homogeneous samples of $\mathrm{g}=12 \mathrm{~mm}$ and split samples of $\mathrm{g}=2 \mathrm{x} 6 \mathrm{~mm}$.

Tests of engineering materials revealed that the basic parameters used for characterising properties of these materials are affected by various agents, such as temperature, humidity, speed of loading, etc. $[2,12]$.Deformation of samples observed during tests of mechanical proper-ties of the alloy made the basis for determining: $R_{m}, R_{0,2}, A_{5}$ and $Z$. Stresses were calculated based on the constitutive relations.

The static tensile test enabled to determine constant parameters characterising the given material, see Fig.1.

The same figure compares static mechanical properties of the examined $7020 \mathrm{M}$ alloy with those of the 7020alloy used in shipbuilding. This comparison reveals that the alloy $7020 \mathrm{M}$ has got Rm and R0,2 higher by $20-25 \%$ than those obtained for the alloy7020, at simultaneous reduction of relative plastic elongation $\mathrm{A}_{5}$ by $\sim 22 \%$.

The results of examination of the alloy $7020 \mathrm{M}$ have led to the conclusion that the sheets made from both metallurgical melts $(507,635)$ meet the PRS requirements concerning mechanical properties and reveal highest strength parameters among all aluminium alloys applicable in ship-building. 
Tab.1. Chemical composition of sheets made of alloys 7020M tb [1]

\begin{tabular}{|c|c|c|c|c|c|c|c|c|c|c|c|c|}
\hline \multirow{2}{*}{$\begin{array}{c}\text { No of } \\
\text { alloy }\end{array}$} & $\mathrm{Zn}$ & $\mathrm{Mg}$ & $\mathrm{Cr}$ & $\mathrm{Zr}$ & $\mathrm{Ti}$ & $\mathrm{Fe}$ & $\mathrm{Si}$ & $\mathrm{Cu}$ & $\mathrm{Mn}$ & $\mathrm{Ni}$ & $\mathrm{Al}$ & $\begin{array}{c}\text { No } \\
\text { of } \\
\text { lot }\end{array}$ \\
\hline 507 & 5.13 & 1.9 & 0.16 & 0.15 & 0.071 & 0.27 & 0.15 & 0.08 & 0.057 & 0.006 & remaining & $\begin{array}{l}108 \\
6\end{array}$ \\
\hline 635 & 4.81 & 1.9 & 0.17 & 0.12 & 0.016 & 0.31 & 0.21 & 0.09 & 0.06 & 0.006 & remaining & $\begin{array}{l}108 \\
5\end{array}$ \\
\hline
\end{tabular}

$\mathrm{R}_{\mathrm{m}}[\mathrm{MPa}]$

$\mathrm{R}_{0,2}[\mathrm{MPa}]$
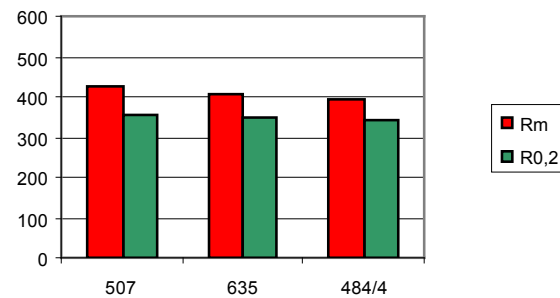

$\square \mathrm{R} 0,2$

$\mathrm{A}_{5}[\%]$
$\mathrm{Z}[\%]$

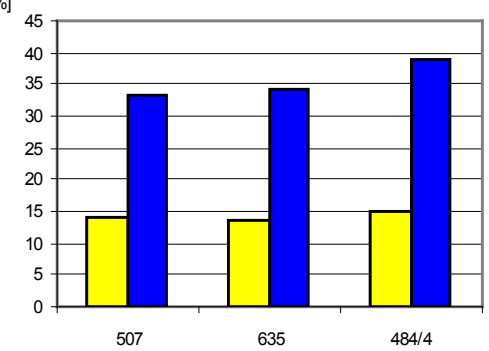

Fig.1. Static mechanical properties of $7020 M$ and 7020 alloys (melts 507 and 635) and 7020 alloy (melt 484/4), samples cut from sheets of $g=12 \mathrm{~mm}$, according to the direction of rolling

The same figure compares static mechanical properties of the examined $7020 \mathrm{M}$ alloy with those of the 7020 alloy used in shipbuilding. This comparison reveals that the alloy $7020 \mathrm{M}$ has got $\mathrm{R}_{\mathrm{m}}$ and $\mathrm{R}_{0,2}$ higher by $\sim 20-25 \%$ than those obtained for the alloy 7020, at simultaneous reduction of relative plastic elongation $A_{5}$ by $\sim 22 \%$.

The results of examination of the alloy $7020 \mathrm{M}$ have led to the conclusion that the sheets made from both metallurgical melts $(507,635)$ meet the PRS requirements concerning mechanical properties and reveal highest strength parameters among all aluminium alloys applicable in ship-building.

\section{IMPACT RESISTANCE OF 7020M ALLOY}

The results of impact resistance tests performed with the aid of the Charpy hammer and the fall-ing hammer on the homogeneous and split samples taken from two melts of 7020M alloy are shown in Figs.2a and Tab. 2, Tab. 3.

Based on the results of examination of 7020M alloy samples performed using the Charpy hammer we can conclude that the impact resistance of 2-layer samples is much higher than that of 1-layer samples, for the same overall dimensions of the samples. The impact resistance of the samples cut out in the rolling direction from sheets with a notch along sheet thickness (Fig.2b) is over three times as high for 2-layer samples as that for 1-layer samples. The 1-layer samples cut out in the direction of sheet rolling and having a surface notch reveal about three times as high impact resistance as those with the notch along their thickness. The 2-layer samples cut out in the direction of sheet rolling and having a surface notch crack only partially, and the decrease of the sample temperature from $+20{ }^{\circ} \mathrm{C}$ to $-20{ }^{\circ} \mathrm{C}$ practically does not affect the impact resistance of the examined alloy.

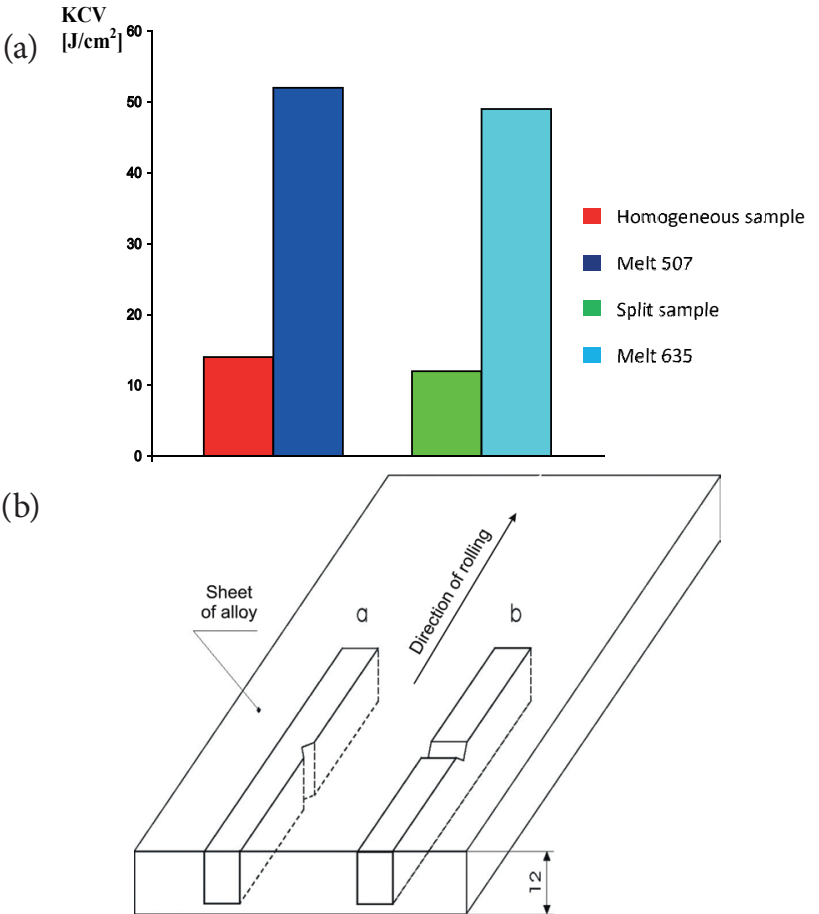

Fig.2. a)-Average impact resistance of homogeneous and split samples $(h 1=h 2=0,5 h)$ of $7020 M$ alloy. Samples taken from melts 507 and 635 b)- Method of cutting samples from a sheet of the examined alloy $7020 \mathrm{M}$

\section{IMPACT RESISTANCE DETERMINED ON THE FALLING HAMMER}

The impact tests were complemented by tests performed on the falling hammer. The ram of this hammer, carrying certain amount of energy, deformed the homogeneous and split samples of the alloy 7020M taken from melts 507 and 635 and mounted in the hammer base, see Fig. 3.

The results of examination of the samples made of the alloy $7020 \mathrm{M}$, performed using the falling hammer (Tables 2 and 3), testify that permanent deflection of 2-layer samples is larger than that of 1-layer samples, which means consuming higher portion of energy of the impact [16].

\section{NUMERICAL VERIFICATION OF RESULTS OF FALLING HAMMER TESTS}

Figure 3 shows a sketch of the geometry of: the hammer base (supports), the examined samples (homogeneous and split, of the same thickness), and the ram of the falling hammer. 


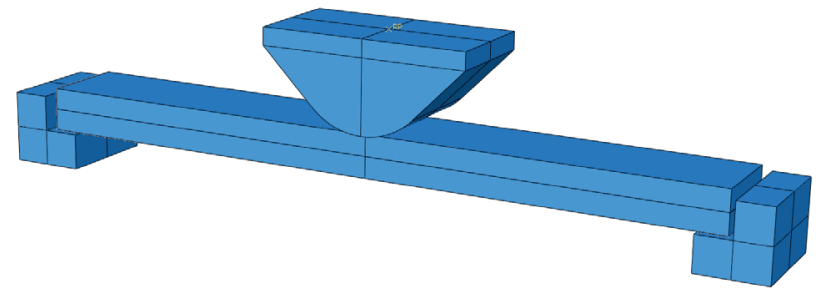

Fig.3. Sketch of geometry of impact set elements

The speed of the ram (mass $\mathrm{m}=28 \mathrm{~kg}$ ) and its kinetic energy at the impact time were calculated using formulas 7 and 8
$\mathrm{V}=\sqrt{ } 2 \mathrm{gh}$
$\mathrm{E}=\mathrm{mV}^{2} / 2$

The above geometry of the task was discretized using 4468 8 -node hexagonal elements, defined in the space by 6299 nodes.

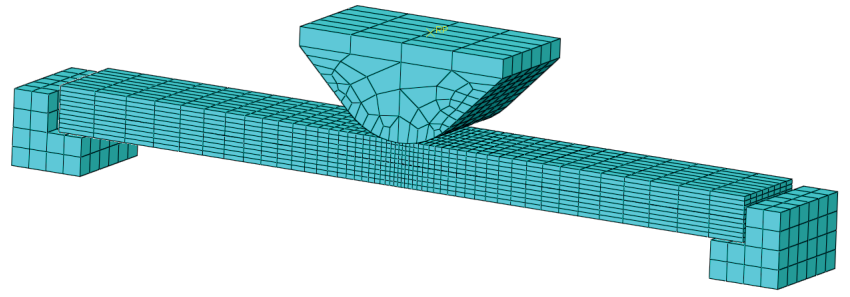

Fig.4. Discretization of elements of the impact set with the falling hammer

The material characteristic of the examined alloy was determined using the Johnson-Cook model described in $[10,15]$

$$
\begin{gathered}
\sigma_{p l}=\left(A+B \varepsilon_{p l}^{n}\right)\left[1+C \ln \left(\frac{\dot{\varepsilon}_{p l}}{\dot{\varepsilon}_{0}}\right)\right] \\
\mathrm{A}=271,43 \mathrm{MPa} ; \mathrm{B}=370 \mathrm{MPa} ; \mathrm{n}=0,24 \\
\mathrm{C}=0,0074 ; \dot{\varepsilon}_{\mathrm{o}}=0.0001 \mathrm{~s}-1
\end{gathered}
$$

For the task prepared in the above way a series of computer simulations were performed using the Finite Element Method (FEM) and the CAE code $[13,14]$. Selected results of the simulation of the impact load applied to the examined alloy samples are shown in Figs. 5-8 for $\mathrm{h}=0,4 \mathrm{~m}$. Permanent deformations of the samples were defined by the quantity $\mathrm{b}$ in Tables 2 and 3.

\begin{tabular}{|c|c|c|c|c|c|c|}
\hline \multirow{2}{*}{$\begin{array}{c}\text { Height of } \\
\text { ram falling } \\
\text { m }\end{array}$} & \multirow{2}{*}{$\begin{array}{c}\text { Ram speed } \\
\mathrm{m} / \mathrm{s}\end{array}$} & \multirow{2}{*}{$\begin{array}{c}\text { Kinetic } \\
\text { energy } \\
\mathrm{N} \cdot \mathrm{m}\end{array}$} & \multirow{2}{*}{$\begin{array}{c}\text { Residual } \\
\text { stress } \\
\sigma_{\mathrm{HMH}} \\
\mathrm{MPa}\end{array}$} & \multicolumn{2}{|c|}{$\begin{array}{c}\text { Deformation } b \\
\mathrm{~mm}\end{array}$} & \multirow{2}{*}{$\begin{array}{c}\text { difference } \\
\%\end{array}$} \\
\hline & & & & simulation & experiment & \\
\hline 0,4 & 2,80 & 109,76 & 250,5 & 34,77 & 34,23 & 1,58 \\
\hline 0,6 & 3,43 & 164,81 & 279,0 & 46,82 & 44,21 & 5,90 \\
\hline 0,8 & 3,96 & 219,54 & 330.0 & 54,37 & 52,0 & 4,55 \\
\hline
\end{tabular}

Tab.2. Parameters of layers of the split sample of the same thickness as the homogeneous sample, both made of $7020 \mathrm{M}$ alloy

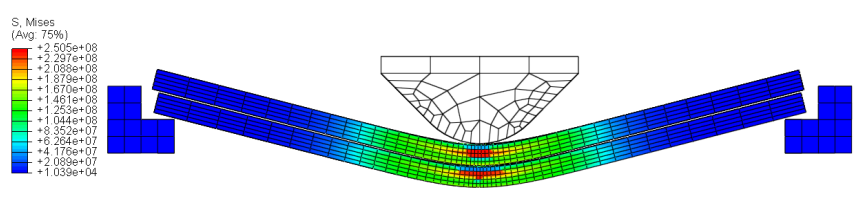

Fig.5. Distribution and values of the residual reduced stress $е \sigma_{\text {Нмн }}$ and the state of deformation for $h=0,4 \mathrm{~m}$. Split sample

Tab.3. Parameters of homogeneous layer made of the alloy $7020 \mathrm{M}$

\begin{tabular}{|c|c|c|c|c|c|c|}
\hline $\begin{array}{c}\text { Height of } \\
\text { ram falling } \\
\mathrm{m}\end{array}$ & \multirow{2}{*}{$\begin{array}{c}\text { Ram speed } \\
\mathrm{m} / \mathrm{s}\end{array}$} & $\begin{array}{c}\text { Kinetic } \\
\text { energy } \\
\mathrm{N} \cdot \mathrm{m}\end{array}$ & $\begin{array}{c}\text { Residual } \\
\text { stress } \\
\text { OHMH } \\
\mathrm{MPa}\end{array}$ & \multicolumn{2}{|c|}{$\begin{array}{c}\text { Deformation } b \\
\mathrm{~mm}\end{array}$} & \multirow{2}{*}{ difference } \\
\cline { 5 - 6 } & & & & & \\
\hline 0,4 & 2,80 & 109,76 & 252 & 27,8 & 32,8 & 8,5 \\
\hline 0,6 & 3,43 & 164,81 & 265 & 31,6 & 35,2 & 10,3 \\
\hline 0,8 & 3,96 & 219,54 & 273 & 41,2 & 43,6 & 5,5 \\
\hline
\end{tabular}

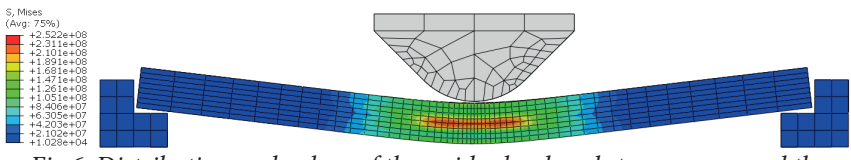

Fig.6. Distribution and values of the residual reduced stress $е \sigma_{\text {нмн }}$ and the state of deformation for $h=0,4 \mathrm{~m}$. Ho-mogeneous sample

Table 4 compares the energy of minimal and maximal total deformation and the energy of plastic deformation. Figure 7 shows a selection of plastic deformation energy density distributions in split samples and a homogeneous sample, for the hammer ram falling from the height of $0,6 \mathrm{~m}$.

Tab.4. Comparing deformation energy and plastic deformation energy

\begin{tabular}{|c|c|c|c|c|c|c|c|}
\hline \multirow{2}{*}{$\begin{array}{c}\text { Height } \\
\mathrm{m}\end{array}$} & Kinetic & \multicolumn{6}{|c|}{ Energy of deformation, J } \\
\cline { 3 - 8 } & $\mathrm{N} \cdot \mathrm{m}$ & $E_{\text {def,max }}$ & $E_{\text {def,min }}$ & $E_{\text {plastic }}$ & $E_{\text {def,max }}$ & $E_{\text {def,min }}$ & $E_{\text {plastic }}$ \\
\cline { 3 - 8 } & 109,76 & 25,9 & 2,1 & 80,2 & 27,1 & 2,6 & 83,7 \\
\hline 0,4 & 29,2 & 2,5 & 136,1 & 30,2 & 3,3 & 145,5 \\
\hline 0,6 & 164,81 & 29,2 & 3,1 & 3,8 & 187,6 \\
\hline 0,8 & 219,54 & 31,1 & 3,1 & 149,9 & 32,3 & 3,8 \\
\hline
\end{tabular}
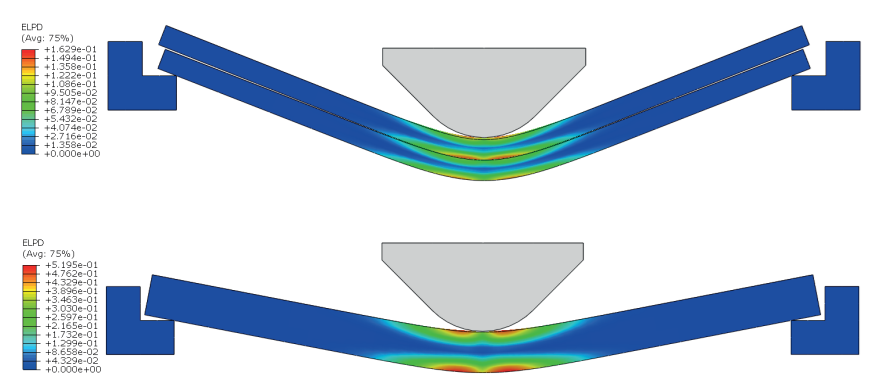

Fig.7. Distribution and values of the plastic deformation energy density for $h$ $=0,6 \mathrm{~m}(\mathrm{~J} / \mathrm{m} 3)$

For the examined alloys 7020M and 7020, the JohnsonCook model adopted for simulation of material properties 
was taken from $[13,14]$ with the following data: density $\rho=2700 \mathrm{~kg} / \mathrm{m} 3$; Young's modulus $-\mathrm{E}=9,1 \cdot 10^{4} \mathrm{MPa}$; Poisson's ratio $-v=0,34$; yield strength $-R_{e}=271,43 \mathrm{MPa}$; strength limit $-\mathrm{R}_{\mathrm{m}}=400 \mathrm{MPa}$.

\section{STRAIN RATE RELATED DYNAMIC PROPERTIES OF 7020 M ALLOY}

The increased strain rate leads to the increase of plastic deformation resistance of metals, with the increase of the yield point, strength limit, and hardness limit as further consequences [4].

The information on impact mechanical properties of the material is needed when evaluating the real impact resistance of the watercraft construction [11]. The strain rate tests were performed for the speed of impact equal to: 10,20 and $30[\mathrm{~m} / \mathrm{s}]$. In Table $5,0[\mathrm{~m} / \mathrm{s}]$ denotes static properties at the impact speed $\mathrm{V} \leq 0-2 \mathrm{~m} / \mathrm{s}$. Detailed results of the examination oriented on determining the effect of strain rate on mechanical properties are collected in Table 5 .

\section{BALLISTIC RESISTANCE OF 7020M ALLOY}

Tests of resistance to perforation (ballistic resistance) were performed by firing a 7,62 $\mathrm{mm} Ł P S$ shell with steel core to homogeneous and split samples $(\phi 50 \mathrm{~mm})$ of the alloy $7020 \mathrm{M}$ from a distance of $1,5-2 \mathrm{~mm}$, while the tests of ballistic (explosive) resistance of homogeneous plates of 12 $\mathrm{mm}$ in thickness and split plates $2 \times 6 \mathrm{~mm}$, both made of $7020 \mathrm{M}$ alloy, were performed by ex-posing the plates to detonation of a high explosive grenade, type OF412, calibre $100 \mathrm{~mm}$, filled with $1,4 \mathrm{~kg}$ TNT, taking place at a distance of $0,6 \mathrm{~m}$ according to STANAG-u 4569.

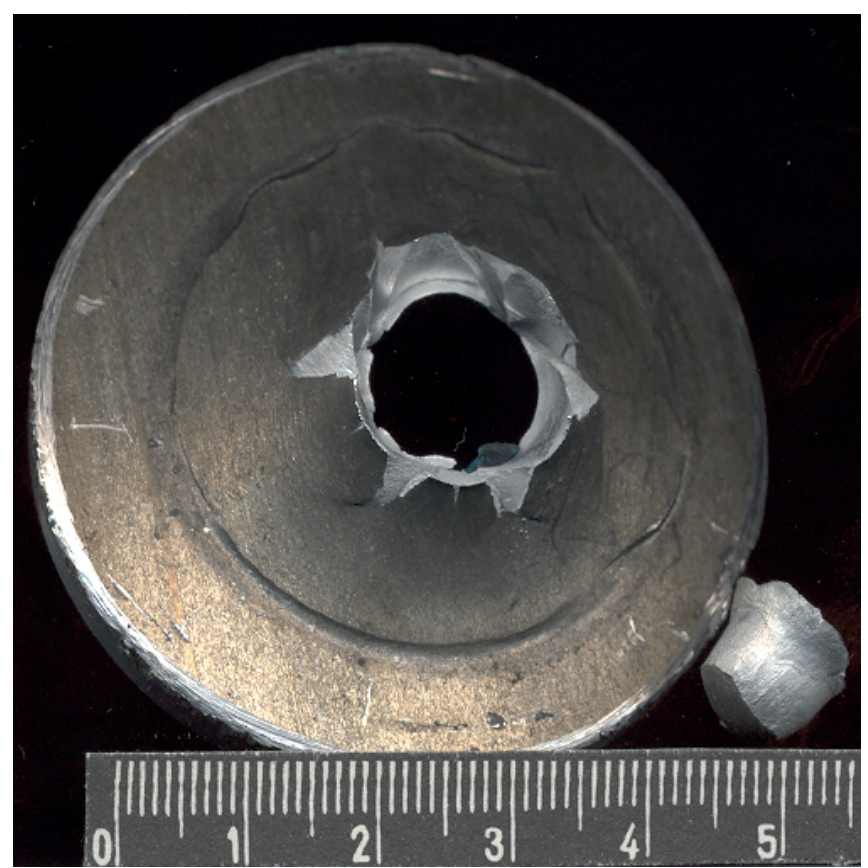

Fig.8a. Effects of firing the $E P S$ shell with steel core and the energy of $3 \mathrm{~kJ}$ to $7020 \mathrm{M}$ alloy from the dis-tance of $2 \mathrm{~m}$ - unprotected sample

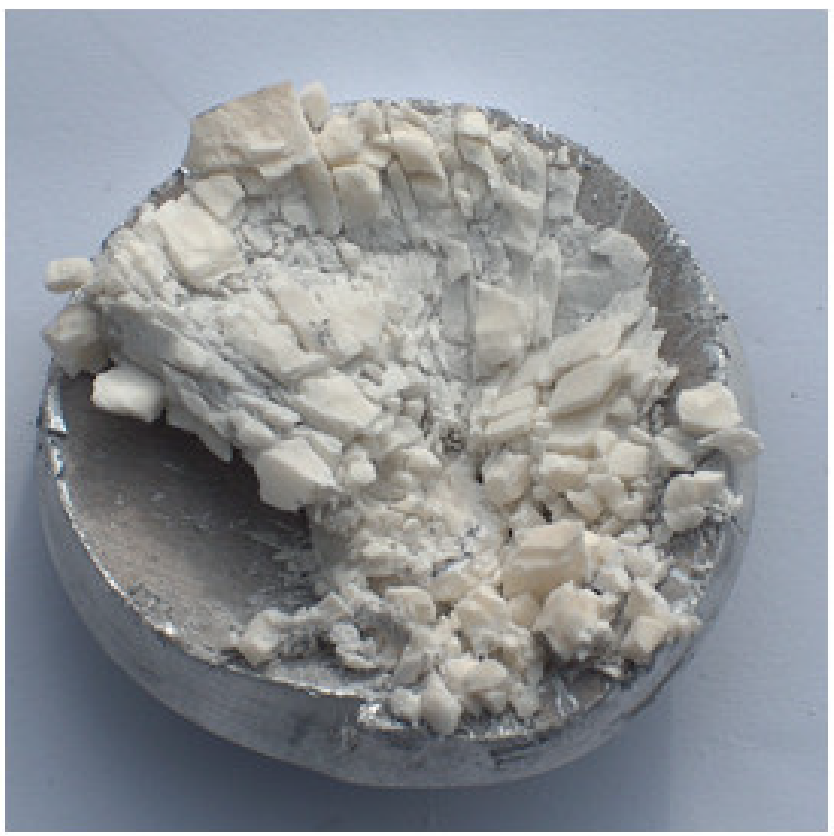

Fig.8b. Effects of firing the EPS shell with steel core and the energy of $3 \mathrm{~kJ}$ to $7020 \mathrm{M}$ alloy from the dis-tance of $2 \mathrm{~m}$ - sample protected with ceramic $\mathrm{Al}_{2} \mathrm{O}_{3}$ of $\mathrm{g}=6 \mathrm{~mm}$

The effects of the action of the air shock wave pressure pulse on the examined homogeneous and split sheets of 7020M alloy are shown in Fig.9.

Compared to the homogeneous plate, the split plates $(g=$ $2 \times 6 \mathrm{~mm}$ ) made of $7020 \mathrm{M}$ alloy re-vealed better capability of minimising the effects of detonation of high explosive charge, thus increasing the safety of navigation in situations threatening with explosion. The perforation of the homogeneous plate seen in Fig.9a reveals that the detonation pieces punch the plate and may pose a threat. In contrary to that, the inner plate shown in Fig.5bw captures part of the pieces while the outer plate, shown in Fig. 9bz, either captures the pieces or entirely cracks (without defragmentation). Such favourable results are not observed in tests checking the resistance to perforation. The examined alloy $7020 \mathrm{M}$, even split in the same thickness, does not protects against the ŁPS shell of calibre 7,62 and energy $3 \mathrm{~kJ}$ which generates pieces during perforation, see Fig.8a. However, total protection in this case can be ensured by an additional layer of ballis-tic ceramic $\left(\mathrm{Al}_{2} \mathrm{O}_{3}\right)$ of $\mathrm{g}=6 \mathrm{~mm}$, as shown in Fig.8b. 
Tab.5. Collation of average dynamic mechanical properties of samples made of 7020M alloy, melts 507 and 635, exposed to different strain rates

\begin{tabular}{|c|c|c|c|c|c|c|c|c|c|c|c|c|c|c|c|c|c|}
\hline \multirow{2}{*}{ Lp. } & \multirow{2}{*}{$\begin{array}{c}\text { Prędkość } \\
\text { odkształcenia } \\
\vee[\mathrm{m} / \mathrm{s}]\end{array}$} & \multirow{2}{*}{\multicolumn{2}{|c|}{$\begin{array}{l}\text { Rodzaj } \\
\text { próbki i } \\
\text { wytopu }\end{array}$}} & \multicolumn{5}{|c|}{ PARAMETRY PRÓBEK PRZED BADANIAMI } & \multicolumn{5}{|c|}{ PARAMETRY PRÓBEK PO ZRYWANIU } & \multicolumn{4}{|c|}{$\begin{array}{c}\text { DYNAMICZNE WŁASNOŚCl } \\
\text { MECHANICZNE }\end{array}$} \\
\hline & & & & $\begin{array}{c}L_{0} \\
{[\mathrm{~mm}]}\end{array}$ & $\begin{array}{c}\mathrm{l}_{0} \\
{[\mathrm{~mm}]}\end{array}$ & $\begin{array}{c}\phi_{0} \\
{[\mathrm{~mm}]}\end{array}$ & {$\left[\begin{array}{c}\mathrm{s}_{0} \\
{\left[\mathrm{~mm}^{2}\right]}\end{array}\right]$} & & $\begin{array}{c}L_{0 k} \\
{[\mathrm{~mm}]}\end{array}$ & $\begin{array}{c}\mathrm{lok}_{0 \mathrm{k}} \\
{[\mathrm{mm}]}\end{array}$ & $\begin{array}{c}\phi_{0 \mathrm{k}} \\
{[\mathrm{mm}]}\end{array}$ & $\begin{array}{c}\mathrm{s}_{0 \mathrm{k}} \\
{\left[\mathrm{mm}^{2}\right]}\end{array}$ & & $\begin{array}{c}\mathrm{R}_{\mathrm{md}} \\
{[\mathrm{MPa}]}\end{array}$ & $\begin{array}{c}\mathrm{R}_{0,2 \mathrm{~d}} \\
{[\mathrm{MPa}]}\end{array}$ & $\begin{array}{l}\mathrm{A}_{6 \mathrm{~d}} \\
{[\%]}\end{array}$ & $\begin{array}{c}\mathrm{Z}_{\mathrm{d}} \\
{[\%]}\end{array}$ \\
\hline 1 & 0 & \multirow{4}{*}{\multicolumn{2}{|c|}{ 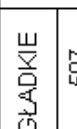 }} & 25.86 & 22.30 & 5.03 & 19.87 & & 29.11 & & 4.19 & 13.79 & & 430.94 & 408.84 & 12.57 & 30.61 \\
\hline 2 & 10 & & & 24.53 & 21.44 & 5.07 & 20.19 & & 28.86 & & 4.07 & 13.01 & & 679.82 & 598.47 & 17.65 & 35.56 \\
\hline 3 & 20 & & & 26.74 & 23.34 & 5.12 & 20.59 & & 31.42 & & 4.04 & 12.82 & & 555.50 & 487.13 & 17.50 & 37.74 \\
\hline 4 & 30 & & & \begin{tabular}{|l|}
24.80 \\
\end{tabular} & \begin{tabular}{|l|}
21.12 \\
\end{tabular} & 5.04 & 19.95 & & 28.86 & & 3.90 & 11.95 & & 508.60 & 423.34 & 16.37 & 40.12 \\
\hline 1 & 0 & $\bar{\square}$ & \multirow{4}{*}{ 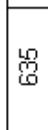 } & 24.73 & 21.25 & 4.99 & 19.56 & & 28.84 & & 3.77 & 11.16 & & 250.77 & 231.54 & 16.62 & 42.92 \\
\hline 2 & 10 & 商 & & 25.55 & \begin{tabular}{|l|}
21.77 \\
\end{tabular} & 5.05 & 20.03 & & 29.33 & & 3.14 & 7.74 & & 571.01 & 477.30 & 14.79 & 61.34 \\
\hline 3 & 20 & 営 & & \begin{tabular}{|l|}
25.10 \\
\end{tabular} & 20.56 & 5.04 & 19.95 & & 32.19 & & 3.18 & 7.94 & & 440.98 & 361.61 & 28.25 & 60.19 \\
\hline 4 & 30 & & & \begin{tabular}{|l}
25.37 \\
\end{tabular} & 21.42 & 5.02 & 19.79 & & 32.12 & & 2.95 & 6.83 & & 483.03 & 423.76 & 26.61 & 65.47 \\
\hline
\end{tabular}
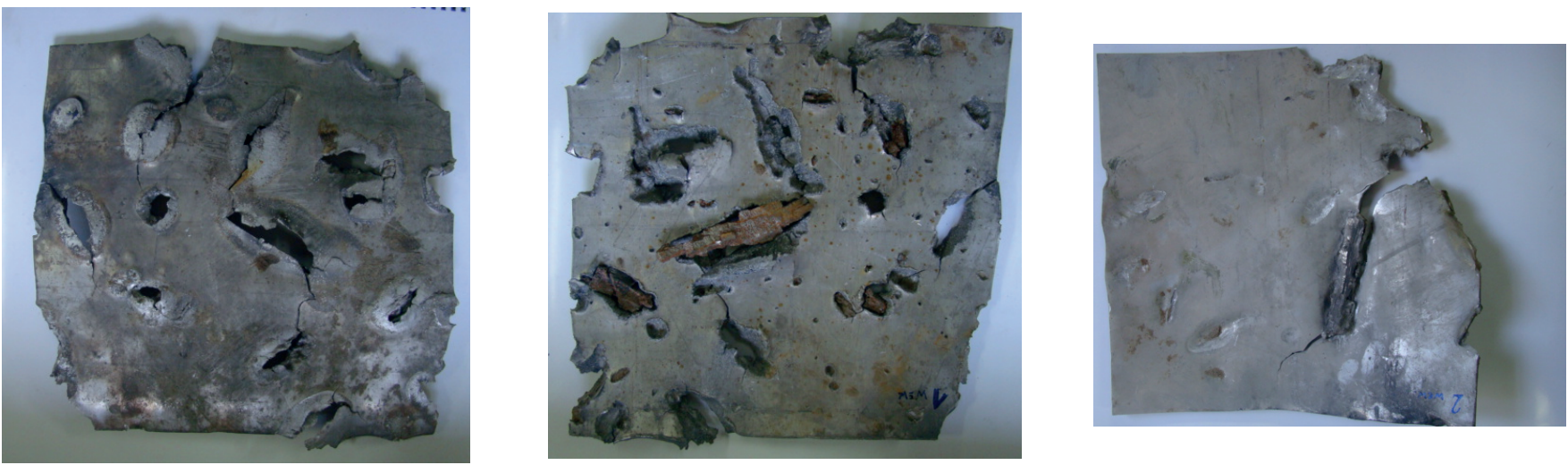

Fig.9. Effects of 7020M alloy sheet perforation (dimensions 300x3000): a) homogeneous $g=12 \mathrm{~mm} b$ ) split ( $w$-inner, $z$-outer from the source of explosion, total thickness $g=2 x 6 \mathrm{~mm}$ ) after detonation of high explosive shell of OF412 type and calibre $100 \mathrm{~mm}$ with the contents of 1,4 $\mathrm{kg}$ of TNT, taking place at a distance of $0,6 \mathrm{~m}$.

\section{FINAL CONCLUSIONS}

The performed tests of samples made of 7020M alloy allow the following conclu-sions to be formulated:

1.The increase of dynamic load has led to the increase of strength parameters of the ex-amined alloy $7020 \mathrm{M}$, as compared to the values obtained in the static tensile test.

2.Strenght and plastic properties of the examined aluminium alloy depend on the strain rate and the load energy density.

3. Conclusions resulting from tests performed with the Charpy hammer

a. Impact resistance of the samples split along the thickness is over three times as high as that of the samples with homogeneous structure along the thickness.

b. Impact resistance of the samples having homogeneous structure along the surface in approximately three time as high as that of the homogeneous samples along the thick-ness.

c. During the Charpy hammer tests, the samples split along the surface did not crack entirely, while the homogeneous samples along the thickness totally cracked

d. The applied adhesive does not affect the impact resistance of the split samples.

4. Permanent deflection of the split samples being the result of the falling hammer action is much larger than that of the homogeneous samples.

The alloy $7020 \mathrm{M}$ is a highly resistant alloy, with $\mathrm{R}_{\mathrm{m}}=$
$=400-500 \mathrm{MPa}$, and simultaneous-ly preserves good plastic properties. Its high resistance to corrosion in sea environment [2], along with neutral reaction to magnetic forces and weldability, make this alloy ap-plicable for constructions of marine transportation means. However, the following recommendations related to terrorist threat safety are to be taken into account when using this alloy:

- important ship compartments made of 7020M alloy should be additionally protected against bullets using ballistic ceramic of minimal thickness of $6 \mathrm{~mm}$.

- marine constructions built using this alloy should have a split structure, provided that technological aspects make it possible.

\section{REFERENCES}

\section{Attestation IMN-OML no. 4550/91,336 OML/91.}

2. Cudny K, Powierża Z.: Selected issues of impact resistance of ships (in Polish). Script WSMW 1978.

3. Dobrociński St., Fila J, Jurczak W.,Kolenda J.: Impact and ballistic resistance of a new aluminium alloy and composites making use of it (in Polish). Statute work of AMW 1999-2001 pk. „BALIDUR” 
4. Fila J.: Examining the effect of the loading state and strain rate on the strength and duc-tility of shipbuilding materials (in Polish). Conference on "Impact resistance of struc-tures", AMW, Gdynia 1993.

5. Fila J., Zatorski Z. et al.: Reports no 1/1993, 1/94, and 2/95 of IPBMO/"Shell" - AMW-KBN 1993-95.

6. Grządziela A., Jurczak W.: Current problem of sea transport safety. Logistyka 6/2014

7. Jurczak W.: The effect of chemical composition and heat treatment on mechanical properties and corrosion resistance of $\mathrm{Al}-\mathrm{Zn}-\mathrm{Mg}$ alloys intended to be used for welded ship constructions (in Polish) . Ph.D. thesis, PG 1998.

8. Jurczak W. Kyzioł L.: Dynamic properties of 7000-series aluminium alloys at large strain rates. Polish Maritime Research 1 (72) vol.19 2012

9. Jurczak W. Kolenda J.: Patent submission - three-layer shield (in Polish), 2004

10. Jurczak W., Szturomski B., Simulating the Impact of Exposure to Corrosive Medium on Cracking Initiation in AW7020M Alloy Specimens, Solid State Phenomena, Trans Tech Periodicals published by Trans Tech Publications Ltd., Zurich, Switzerland 2014,
11. Kinslov R. at al.: High-Velocity Impact Phenomena. Academic Press, New York and London, 1970.

12. Levedahl W., Capable A.: Affordable 21st - Century Destroyer. Naval Engineers Journal. May 1993, pp. 213223

13. Szturomski B.: Principles of the Finite Element Method (in Polish), Wydawnictwo Akademickie Akademii Marynarki Wojennej w Gdyni, Gdynia 2011

14. Szturomski B.: Engineering applications of FEM for solving solid body problems, as illustrated by the code ABAQUS (in Polish), Wydawnictwo Akademickie Akademii Marynarki Wojennej w Gdyni 2013

15. Szturomski B., Jurczak W.: Operating wear of ship aluminium alloys 7020 and 7020M (in Polish), Energetyka, Wortal Branżowy, no. 8 (698) 2012,

16. Wiśniewski A.: Armours - structure, designing and testing (in Polish). WNT, War-saw 2001

\section{CONTACT WITH THE AUTHOR}

\author{
Wojciech Jurczak \\ The Naval Academy \\ Name of Heroes of the Westerplatte \\ 69 Śmidowicza Str. \\ 81-103 Gdynia \\ POLAND
}

